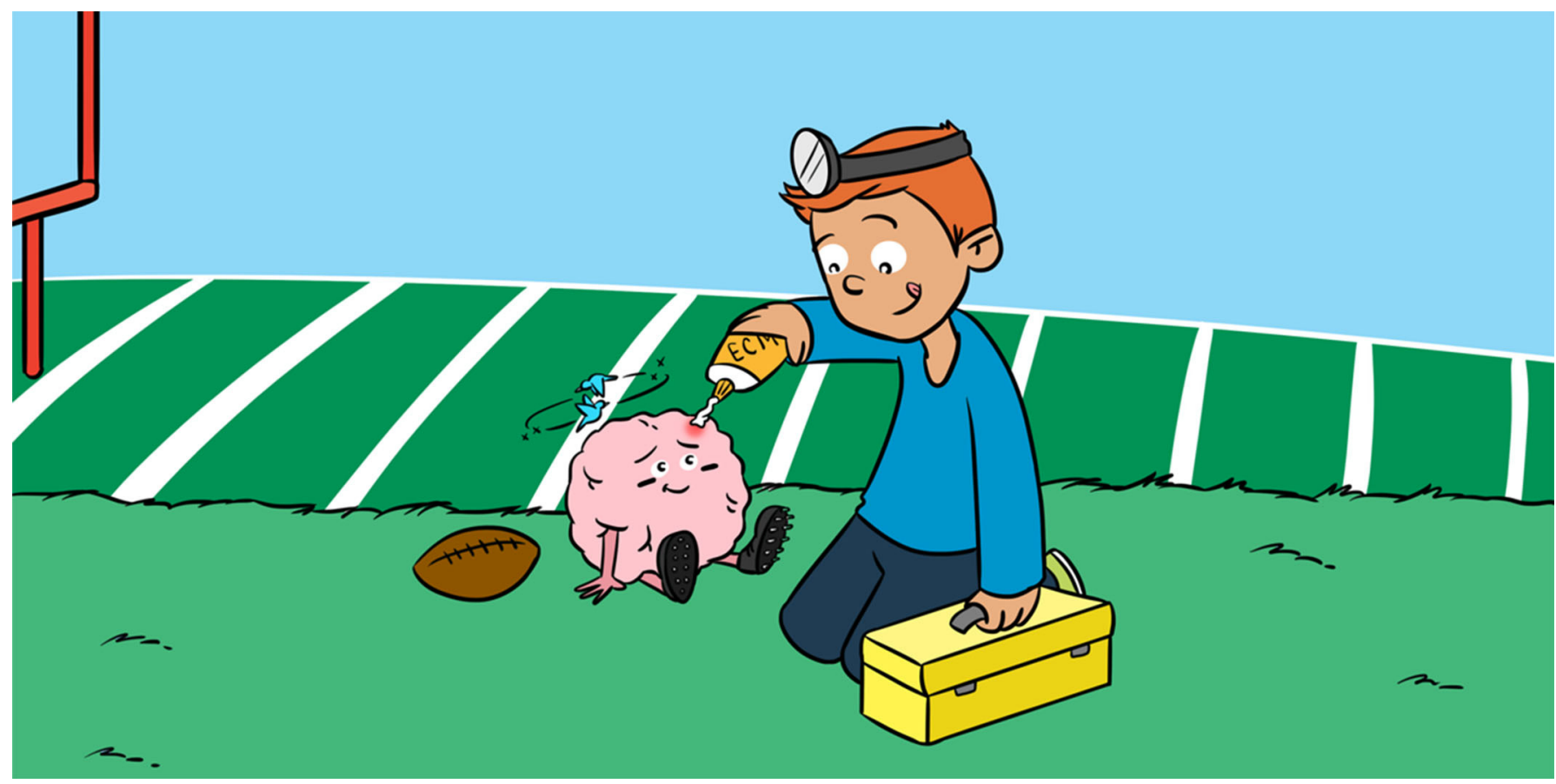

\title{
TISSUE ENGINEERING IN TRAUMATIC BRAIN INJURIES
}

\section{Judy Tanios $^{1+}$, Sarah Al-Halabi ${ }^{2+}$, Hiba Hasan ${ }^{1,3+}$, Samar Abdelhady ${ }^{1,4}$, John Saliba ${ }^{1}$, Abdullah Shaito ${ }^{5^{*}}$ and Firas Kobeissy ${ }^{1^{*}}$}

${ }^{1}$ Department of Biochemistry and Molecular Genetics, Faculty of Medicine, American University of Beirut, Beirut, Lebanon

${ }^{2}$ Department of Biology, Faculty of Arts and Sciences, American University of Beirut, Beirut, Lebanon

3 Institute of Anatomy and Cell Biology, Justus-Liebig-University Giessen, Giessen, Germany

${ }^{4}$ Faculty of Medicine, Alexandria University, Alexandria, Egypt

${ }^{5}$ Department of Biological and Chemical Sciences, Lebanese International University, Beirut, Lebanon

YOUNG REVIEWERS:

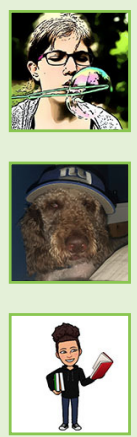

ARIANA

AGE: 12

LUCIEN

AGE: 12

NAOMI

AGE: 12
If the brain is injured due to traumatic brain injury (TBI), it will lose some of its cells. If our brain cells get damaged, we may be left with problems controlling our movement, our speech, or even our memory! In the future, tissue engineering may be able to help people with TBI. Tissue engineering involves building a piece of tissue outside of the body or assisting the damaged part of a tissue to grow again and function inside the body. Cells are the building blocks of the body, and they are surrounded by a matrix that supports them. This matrix is called the extracellular matrix (ECM). Scientists can make artificial mimics of the natural ECM. The artificial ECM helps a damaged tissue to regenerate. In this article, we discuss how Gel-MA, an artificial $E C M$, can have healing properties in injured brains. 
REGENERATIVE

\section{CAPACITY}

The ability of the body to repair and replace cells, tissues, or organs lost due to injury or disease.

CENTRAL NERVOUS SYSTEM

The bodily system composed of nerve tissues. It controls the activities of the body. In vertebrates, it includes the brain and the spinal cord.

TRAUMATIC BRAIN INJURY

Damage caused to the brain by a bump to the head. The injury usually disrupts normal brain functioning.

\section{INTRODUCTION}

Did you know that a lizard can regrow its cut-off tail? This property is called regeneration. Regeneration is an ability that is not unique to lizards. Many animals can regenerate parts of their bodies to replace damaged ones. When a certain flatworm is cut into pieces, each piece of the flatworm can turn into a whole new worm! A starfish can regrow a new arm if it loses one, and sometimes an arm can grow into an entire starfish. Humans can also regenerate, but to a lesser level. For example, have you ever wondered why, when we accidentally cut ourselves with something sharp, we later find it healed with no marks of the injury, apart from occasional scarring? This is due to the regenerative capacity of the skin. Unfortunately, not all our body parts and tissues can repair themselves, and some never do so.

\section{THE HUMAN BRAIN}

Our brains are like machines that work day and night. We do not think about most of the things that our brains control, like breathing, regulating our heartbeats, and digesting the food that we eat by moving the muscles of the stomach.

The brain is a complex organ and is part of what we call the central nervous system. There are two main types of brain cells: neurons and glial cells (Figure 1). Neurons are the key players for information processing. There are around 100 billion neurons in your brain; equal to the number of the stars in the Milky Way Galaxy. Neurons are the cells that make you able to think, learn, memorize things, and transmit messages to other parts of your body. Glial cells are cells that support the neurons. They act like housekeepers or nurses of the brain; they provide neurons with adequate nourishment, they clean up dead neurons, and they protect the living neurons from infection by foreign organisms.

The neurons connect with each other to make a network that allows the brain to perform its functions. If only few neurons in the brain become damaged or dead, then such a small disruption in the neuron network may not be noticed by the affected person. However, if many neurons die, the affected person may suffer from problems with movement, memory, speech, or thinking, etc. When the brain loses too many neurons, it cannot replace them all. This is because the brain, unlike the skin, cannot regenerate. So, protecting this vital organ is a must!

One important thing to know about the brain is that if it shakes, it breaks. A head injury that results from a strong blow or a fall can traumatize the brain. This can disrupt the normal functions of the brain. Such an injury is called traumatic brain injury (TBI). Different bumps to the head can lead to different types of TBI, ranging from mild, to 
Figure 1

The 3D structure of brain cells: brain cells and their surrounding extracellular matrix (ECM). The human brain is made up of 2 main types of cells as shown in the enlarged area (upper right). The enlarged area also shows brain cells surrounded by the extracellular matrix (ECM). The ECM is made up of a network of biological molecules as shown in the enlarged circle (lower left). The ECM surrounds the neurons and makes a 3D structure around the cells, giving them their shapes and helping them to perform their functions. Two main types of brain cells, neurons and glial cells, are detailed in the enlarged area in the upper right. These cells vary in shape, structure, and function. Neurons process and transmit information to other body systems and organs. Glial cells support neurons with nutrients and protect the whole brain from cellular damage and infection by foreign organisms.

\section{REGENERATIVE MEDICINE}

Regenerative medicine is the branch of medicine that develops methods to replace or regenerate human cells, tissues or organs, in order to restore or establish normal function. The impaired function can be the result of any cause, including birth defects, disease, trauma, or aging

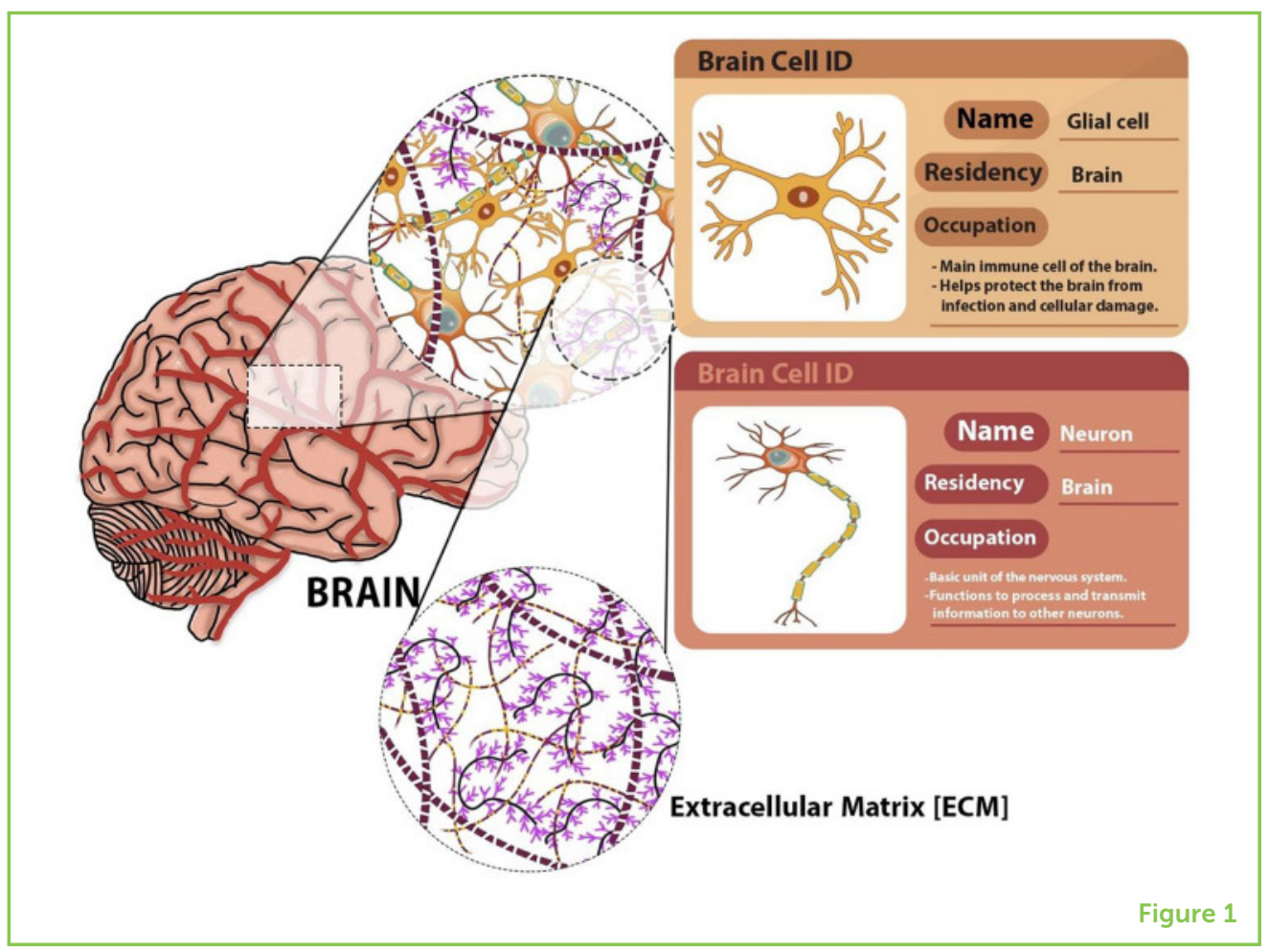

moderate, to severe. The symptoms from a trauma to the brain depend on how severe and frequent the TBI is. In fact, these brain injuries are not rare. Concussions, which may happen when we fall off a bike, play sports, or get in a car accident, are one form of TBI.

\section{REGENERATIVE MEDICINE TO THE RESCUE}

A hit to the brain can injure some neurons and even cause them to die. The dead neurons cannot be properly replaced. This is similar to an explosion that causes some buildings to collapse. Obviously, buildings cannot reconstruct themselves. Engineers and workers are needed to fix the damage. If we apply the same concept to injured body parts (such as the brain), regenerative medicine can act as the engineers and workers and could save the day [1].

Thanks to regenerative medicine, restoration of body functions that are damaged due to an injury or a disease is now possible. Regenerative medicine can be used to treat diseases such as those of the nervous system and of the heart. Regenerative medicine can also replace or repair tissues and organs that are damaged by trauma (like $\mathrm{TBI}$ ) or by aging. Regenerative medicine can help in two ways. First, it can use cells made outside the body to replace the lost or damaged cells in the body. Second, it can increase the production of new cells inside the body. These regenerative medicine approaches can enhance tissue function, reduce disabilities, and improve the quality of life [2]. 
TISSUE

\section{ENGINEERING}

A sub-branch of regenerative medicine. It applies the principles of engineering and life sciences toward the development of biological substitutes that can restore, maintain, or improve tissue function or a whole organ. The biological substitutes include biomaterials, cells, and biologically active molecules. The biological substitutes can be used to create tissues or cellular products outside the body or help the repair of tissues within the body.

\section{EXTRACELLULAR} MATRIX (ECM)

A three-dimensional network of biological molecules present around cells. It provides support to the cells it surrounds.

\section{TISSUE ENGINEERING AND THE MAGICAL GLUE}

Tissue engineering is one new field of regenerative medicine. It combines life sciences with engineering and applies the principles of both fields. Tissue engineering focuses on developing tissues outside the living body that can be used to restore or maintain a body function or even to replace a whole organ.

Cells are the building blocks of tissues, and they are connected using a sort of glue. This glue is called the extracellular matrix or ECM. The ECM makes a 3D structure around the cell, which helps to keep its shape (Figure 1). This 3D structure helps cells to communicate with each other and allows them to function properly. Each type of cell (brain cells, heart cells, etc.) has its unique kind of ECM. Only the ECM specific for a particular cell type can allow that cell type to function properly. One form of tissue engineering, tries to supply cells with a proper ECM glue to help repair damaged cells. The best glue is the one that most closely resembles the original ECM inside the tissue. For example, to have functional brain cells, we need to use an ECM similar to the natural ECM that surrounds brain cells inside the body. This is because only the brain ECM supplies the brain cells with their proper 3D structure.

When engineering a tissue, scientists use cells that they grow in the lab and/ or an ECM glue. They can build the whole tissue in the lab and then implant it into the person who needs it. Another option is to directly provide the damaged tissue with the substances it needs to rebuild itself. In that case, the ECM glue can be added to the damaged tissues without the need to add cells [3].

\section{GEL-MA, A PROPER ECM FOR TBI TREATMENT}

One of the challenges of brain disorders such as TBI is that the damaged neurons are hard to replace. While it is hard for neurons to regenerate by themselves, scientists work hard to make that happen. Since it is not ethical to experiment on the brain of a living human being, scientists use cells growing in small plastic dishes called cell culture dishes (Figure 2A). In our lab, we grow special cells that perform similar functions to neurons. These special cells are cultured on an artificial ECM that we call Gel-MA. Gel-MA is a type of gel made up of gelatin (gelatin is what gives jelly its texture). We have tested the effects of Gel-MA to see if it can help the cells to grow. We grew the special cells with different amounts of Gel-MA. We cultured the cells in the cell culture dishes for one day and then checked how they were growing. We found that, as we increased the amount of Gel-MA, more cells lived. This means that the Gel-MA helped these special brain cells to grow better (Figure 2A). 


\section{Figure 2}

Gel-MA is a potential ECM for treating brain injuries. (A) Special cells called PC12, which are a lot like neurons, were grown in cell culture dishes. When Gel-MA was added to the cells, they increased in number. (B) Gel-MA was applied directly to the injured brains of mice, to study its beneficial and healing effects in TBI. Gel-MA decreased the size of the injury when applied to injured brains and helped the glial cells and neurons to function better

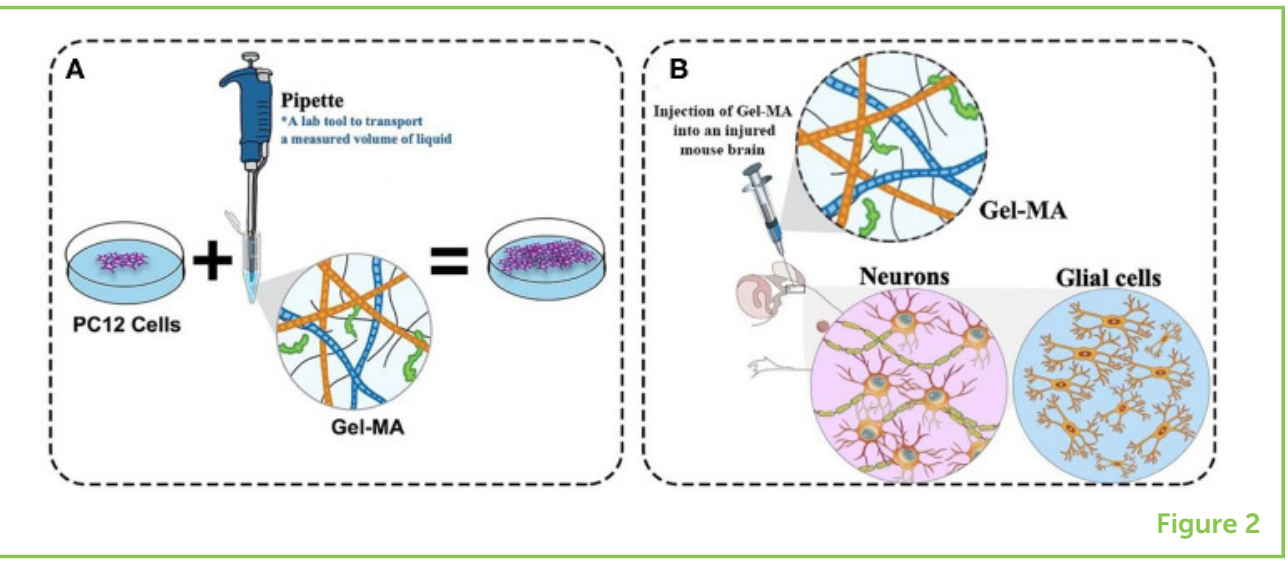

In another experiment, we tested whether Gel-MA could protect neurons from damage by TBI. For this, we used mice that we subjected to TBI. We placed a drop of Gel-MA at the place of head injury. After a week, the mice were still alive, which means that the gel did not have toxic effects. When we checked the brains of the injured mice, we found that the injuries were almost gone 1 week after adding Gel-MA. Now, we are testing whether Gel-MA, added to the injured brains of mice, can improve the behavior of these mice or if they can perform mental tasks better. If we see an improvement, this means that Gel-MA helps to heal brain injuries and can restore brain functions (Figure 2B).

\section{CONCLUSION: THE IMPACT OF GEL-MA}

We use Gel-MA because it can help neurons establish their proper 3D structure. This is similar to what the natural ECM does in the brain. Another important point is that Gel-MA is not toxic to cells, on the contrary, it enhances their growth. This is exciting because it means that, by using an artificial ECM, we are now able to help the injured brain during its healing process [4]. We saw from our experiments that Gel-MA has healing properties during TBI. Our hope is that, in the future, scientists can improve TBI treatment using Gel-MA or other forms of tissue engineering. The brain, which was long thought to be irreparable, now has the promise of repair. Gel-MA could provide an exciting method for treating TBI. Now we must translate our findings from mice to humans, so that we will be able to deal with the important, worldwide issue of TBI!

\section{ORIGINAL SOURCE ARTICLE}

Al Rifai, N., Hasan, A., Kobeissy, F., Gazalah, H., and Charara, J. 2015. "Culture of PC12 neuronal cells in GelMA hydrogel for brain tissue engineering," in 2015 International Conference on Advances 
in Biomedical Engineering (ICABME). p. 254-7. doi: 10.1109/icabme. 2015.7323300

\section{REFERENCES}

1. Mondello, S., Schmid, K., Berger, R. P., Kobeissy, F., Italiano, D., Jeromin, A., et al. 2014. The challenge of mild traumatic brain injury: role of biochemical markers in diagnosis of brain damage. Med. Res. Rev. 34:503-31. doi: 10.1002/med.21295

2. Colombo, F., Sampogna, G., Cocozza, G., Guraya, S. Y., and Forgione, A. 2017. Regenerative medicine: clinical applications and future perspectives. J. Microsc. Ultrastruct. 5:1-8. doi: 10.1016/j.jmau.2016.05.002

3. Kim, Y., Ko, H., Kwon, I. K., and Shin, K. 2016. Extracellular matrix revisited: roles in tissue engineering. Int. Neurourol. J. 20:S23-9. doi: 10.5213/inj.1632600.318

4. Al Rifai, N., Hasan, A., Kobeissy, F., Gazalah, H., and Charara, J. 2015. "Culture of PC12 neuronal cells in GelMA hydrogel for brain tissue engineering," in 2015 International Conference on Advances in Biomedical Engineering (ICABME) Beirut. p. 254-7. doi: 10.1109/icabme.2015.7323300

SUBMITTED: 24 November 2019; ACCEPTED: 22 December 2020; PUBLISHED ONLINE: 10 February 2021.

EDITED BY: Robert T. Knight, University of California, Berkeley, United States

CITATION: Tanios J, Al-Halabi S, Hasan H, Abdelhady S, Saliba J, Shaito A and Kobeissy $F$ (2021) Tissue Engineering in Traumatic Brain Injuries. Front. Young Minds 8:514428. doi: 10.3389/frym.2020.514428

CONFLICT OF INTEREST: The authors declare that the research was conducted in the absence of any commercial or financial relationships that could be construed as a potential conflict of interest.

COPYRIGHT @ 2021 Tanios, Al-Halabi, Hasan, Abdelhady, Saliba, Shaito and Kobeissy. This is an open-access article distributed under the terms of the Creative Commons Attribution License (CC BY). The use, distribution or reproduction in other forums is permitted, provided the original author(s) and the copyright owner(s) are credited and that the original publication in this journal is cited, in accordance with accepted academic practice. No use, distribution or reproduction is permitted which does not comply with these terms.

\section{YOUNG REVIEWERS}

\section{ARIANA, AGE: 12}

My name is Ariana and I am 12 years old. Some of my favorite hobbies are reading, ice hockey, and music. I play the clarinet and the piano. My favorite series is Harry Potter and I can read about a book a day! I also love doing fun science and art experiments. 

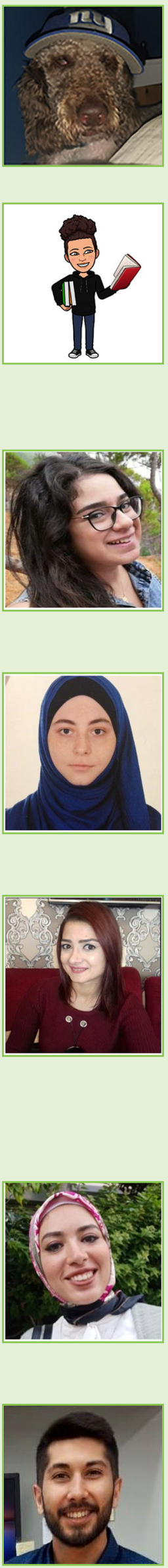

\section{LUCIEN, AGE: 12}

My name is Lucien. I am a sixth grade student. My favorite subjects are math, science, and STEM. My favorite sports are hockey, tennis, and skiing. Other things I enjoy are 3D rendering, graphic design, gaming, and streaming on the PC that I built. I have two little sisters. When I am not picking on them I like cooking breakfast for them.

\section{NAOMI, AGE: 12}

My name is Naomi, and I am in sixth grade. In my free time I enjoy reading, playing sports, and playing piano and French horn. I am the oldest sibling and I have two younger brothers who are really annoying.

\section{AUTHORS}

\section{JUDY TANIOS}

I am currently a junior embryologist at an IVF clinic, committed to making miracles happen for those who lost hope of having children. I am also volunteering at Dr. Firas Kobeissy's lab at the American University of Beirut to fulfill my passion for research. I love to read scientific publications even in my free time. I also love watching movies and have at least one movie night with friends each week.

\section{SARAH AL-HALABI}

I graduated from the Lebanese International University with a degree in biochemistry. I am currently studying for my Master's degree in Biology at the American University of Beirut. My research interests include cancer, transcriptomics, proteomics, and microbiology. I want to eventually complete a Ph.D. in Biology or Biochemistry.

\section{HIBA HASAN}

I am currently a volunteer in the Biochemistry and Molecular Genetics department at the American University of Beirut. The lab focuses on understanding the pathological basis of brain injuries and tests cell- and drug-based therapies for traumatic brain injuries. I have a Master's in Biology with a specialization in Immunology, where I tested the anti-inflammatory and antioxidant activities of different natural agents on autoimmune diseases. I hope to pursue a Ph.D. focusing on the immunopathological basis of autoimmune disorders and hope to find a cure for such diseases.

\section{SAMAR ABDELHADY}

I am a medical doctor. I did a research internship in Dr. Kobeissy's lab at the American University of Beirut (AUB) to study traumatic brain injury [TBI] using animal models. In my free time, I love drawing scientific illustrations and brain art, watching movies that talk about the brain, and since I work for long hours at a desk, I enjoy going hiking to keep my body fit.

\section{JOHN SALIBA}

I am a Ph.D. candidate in biomedical engineering at the American University of Beirut. My research interest is in neuroscience, biomaterials, drug delivery, and cancer. I have a Master's degree in BioMEMS and a Bachelor's in Physics. I have a passion for learning new things and understanding how the world around me works. I hope that 

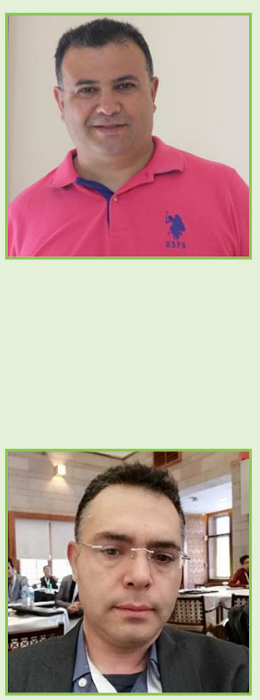

I can contribute to improving patient healthcare through new scientific findings and new approaches to therapy.

\section{ABDULLAH SHAITO}

I obtained my Ph.D. at the University of Texas Southwestern at Dallas (Texas, USA), where I studied microbiota interaction with intestinal cells. Currently, I am an Assistant Professor at the Lebanese International University (Beirut, Lebanon). The current research projects I am working on include the use of stem cells to treat $\mathrm{TBI}$, and the cell-cell communication that happens in different cancers. I also teach several core Biology courses to undergraduates. Email me when you get into college and need help in your Biology courses. *abdshaito@gmail.com

\section{FIRAS KOBEISSY}

I am a neuroscientist with extensive experience in experimental brain injury. I am an assistant Professor at the Department Biochemistry at the American University of Beirut. I obtained my Ph.D. from the University of Florida in the area of neuroscience. My current research focuses on identifying biomarkers for drug abuse toxicity and traumatic brain injury neuroproteomics. I am a member of the Center of Neuroproteomics and Biomarker Research and the Center for Traumatic Brain Injury Studies at the McKnight Brain Institute at the University of Florida. *firasko@gmail.com

${ }^{\dagger}$ These authors have contributed equally to this work 